\title{
ANALYSIS OF SOME OF THE APPLICABLE OUTSOURCING SERVICES IN THE STRUCTURES OF THE BULGARIAN ARMED FORCES
}

\author{
Nikolay STEFANOV \\ "Vasil Levski”" National Military University, Veliko Tarnovo, Bulgaria \\ niki.s@abv.bg
}

\begin{abstract}
Supplying the Bulgarian Army with the necessary material resources is an extremely important activity. This is an activity with a fundamental significance for making quality logistics decisions on strategic, operational and tactical levels. Therefore, it is necessary to analyse the issues related to the use of outsourcing services in the armed forces. They are implemented in the field of defence primarily in the sphere of utilisation of unnecessary munitions, catering, providing various public utilities, repair and maintenance of equipment and provision of security to military sites. Despite of its limited application, outsourcing is currently an important tool for conducting a great number of the logistics activities, providing support of the combat and special training of military formations and the execution of their specific tasks. This article studies and analyses the use of outsourcing services for providing catering for the personnel in the structures of the Bulgarian Armed Forces and for protection of the military territories.
\end{abstract}

\section{Keywords: outsourcing services, analysis, Bulgarian Armed Forces, catering, security}

\section{Introduction}

Outsourcing is a strategic management approach which is needed to meet the needs of the armed forces regarding their renovation and improvement. It is a system open to external sources of supply of goods and services, and certain activities related to supporting the armed forces are outsourced, i.e. transferred to organisations that are not part of defensive structures - construction, supply of material resources, catering, etc [13]. Its appearance was caused by the need to streamline the activities of the structures in the defence sector in modern conditions. This need is achieved within a comprehensive and consistent process.

A prerequisite for the use of outsourcing services is the opportunity for savings. Factors of great importance are concentrating on the implementation of the main specific tasks, improving the quality of products and services transferred for outsourcing, gaining access to the latest technologies, attracting qualified professionals and the opportunity to share the risk in the performance of certain services.

The application of outsourcing in the armed forces follows the established trends worldwide related to a gradual switch from using single traditional services to the implementation of complex outsourcing services offered by specialised companies [14].

2. Analysis of the use of outsourcing services for providing catering for the personnel in the structures of the Bulgarian Armed Forces

Supplying the Bulgarian army with the necessary material resources is an 
extremely important activity. This is an activity which has a fundamental role on a making quality logistics decisions for strategic, operational and tactical level. For this reason, pursuant to a decision of the Defense Council made on 02.06.2012 and a letter with a Reg. № 101-228/14.02.2006 of the Chief of General Staff [5], catering was introduced in the Bulgarian Armed Forces units. It started on 01.12.2006, and Veselin Bliznakov, the Minister of Defence at that time, signed contracts with four companies for the catering of 43 military units $[7,8]$.

An important feature of the demand for outsourcing services are the motives of the army as a customer. The main motives proved to be the quality and reliability of service. [15]

The idea is to achieve savings of financial resources, as well as use the possibility for external providers to take complete care of feeding the military personnel, and the personnel in the units will provide the specialised training [10].

An example for the preference and use of outsourcing services in the field of catering are the National Military University, the National Guards Unit and the Nikola Yonkov Vaptsarov Naval Academy.

The catering at the Vasil Levski National Military University is performed under a contract with Reg. № 1729/27.05.2011 between the university and the company Nove Trading LTD based in Sofia. The contract is concluded for a period of four years and requires the external provider to prepare and distribute in the premises of the university dishes /cooked food, personal rations and packed meals/ for the daily feeding of cadets, NCO cadets, course participants and officials three times a day, specified by type, quantity, energy values and values in daily food allowance in a weekly menu.

According to a letter with a Reg. № $1240 / 25.03 .2014$, sent by the Rector of the Vasil Levski National Military University to the head of the Logistics Directorate and the justification pointed out in it by the then senior deputy chief of the Logistics section, the benefits for the Military University from the use of outsourcing services for catering are the following [6]:

$\circ$ the external provider must ensure monthly, according to the season, varied and nourishing food by presenting at least 12-15 kinds of snacks, at least 15-18 kinds of soups, at least 18-20 kinds of main dishes, and at least 16-18 kinds of desserts including a variety of fruits, in each variant of the weekly menu;

o the provider must prepare three variants of the current menu in different faculties;

0 the groups of foreign students eat a variant of the weekly menu, consistent with the characteristics of their national cuisine and their religion;

o saving financial resources and a possibility for redirecting them to other categories because of:

- payment of fee by the external provider for the used premises and the equipment provided by the university amounting to 8229.20 levs;

- construction and renovation completed by 01.07 .2011 and kitchen equipment purchased by the supplier and donated to the Rector of the National Military University in the amount of $703,836.92$ levs;

- overhead costs resulting from the difference between the value of the overhead costs specified in the current ministerial order № OH-482/30.07.2010 regulating the feeding, i.e. 2.77 levs including VAT, and the amount paid by the university set in an agreement with Reg. №1729/27.05.2011 - 0.96 levs including VAT;

- transportation costs for the supply of food and the fact that it is the provider who pays the utilities, such as electricity, water, etc.;

- savings from not paying salaries to own personnel for the preparation and distribution of food;

- elimination of the need for having officials on duty at the nutrition sector, 
and hence the costs associated with them;

- no need to provide cleaners, disinfectants and washing liquids, as well as washing powder for washing the table cloths and other material property;

- cost savings of funds allocated for daily control samples of the food.

The data provided in the rationale referred to in a letter with a Reg. № $1240 / 03.25 .2014$ can be summarised in the following analysis which compares the cost of using outsourcing services for the provision of catering and the nutrition organised with the university's own resources - Figure 1 [6].

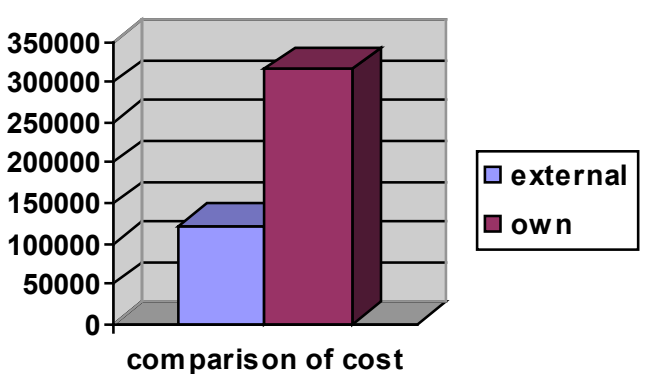

Figure 1: Comparison of cost for the National Military University with the different catering models for the period of six months

From everything stated so far, it becomes obvious that the use of outsourcing services by the National Military University for catering provides it with the opportunity to save financial resources and use them for other purposes.

Another representative of the armed forces using an external contractor for the preparation and delivery of food is the National Guards Unit. This is also one of the first formations, preferring the use of outsourcing services for catering. The success of using such services in this formation is evident. This conclusion lis based on the reasoned request of the deputy commander for logistics supply of the National Guards Unit, expressed in a memorandum written in 2015 to the commander of the National Guards Unit [1]. The request is based on the contract which expired in 2014 concerning the supply of ready-made food to the military unit and Art. 16, Para. 8 in conjunction with Art. 14, Para. 1, Point 2 of the Law on Public Procurement, and demands a procedure to be conducted for selecting a contractor for the preparation and delivery of food to the National Guards Unit for a period of sixty months.

Another example for using outsourcing services for catering purposes is the Nikola Yonkov Vaptsarov Naval Academy. The academy has provided catering to cadets, military and civilian personnel through an external provider from 2007 to the present. Thus, by using outsourcing services in the field of nutrition from 2007 to 2014 the Naval Academy managed to provide quantitative and qualitative nutrition under the current regulations, and the overhead costs are lower almost twice than the projected costs in the ministerial order. Besides providing food, the benefit of using this type of service, as in other institutions and units, is a substantial renovation of the kitchen sector and the dining areas peformed by the external service provider [2].

The analysis of the available literature (Peicheva, 2013; Dimitrova et al., 2015; Terziev et al., 2016; Nichev, 2011; Morkin, 2012 ,etc.) allows to summarise the following benefits of using outsourcing services to provide food to soldiers and civilian employees of the Bulgarian Armed Forces: $[4,12,16]$

- a balanced, rational and varied diet, specified in the contract requirements;

- relatively low overheads;

- clearly defined criteria for pricing the dishes in the contracts;

- reducing the practices for the use of official position for personal gain;

- effective opportunity to carry out daily control over all the clauses of the contract by the contracting authority; 
- renovated kitchen and dining facilities at the expense of the contractor;

- meal fee to selected meals (lunches) and quick snacks at reasonable prices;

- opportunity to negotiate feeding against payment for military and civilian personnel who do not receive free food;

- opportunity to negotiate catering for the personnel during exercises, classes, trainings and other events;

- high level of food and service culture of the personnel;

- dispensation of the personnel from unusual activities.

The transition from military catering to catering by an external provider raises a problem related to the food supply of the contingents employed in operations abroad. Outsourcing is not attractive for domestic companies because of the small size of Bulgarian contingents. Supply through own bodies is an extremely difficult task because of the large financial costs associated with the delivery of food to such a great distance [11]. In this case, the it is profitable to use multinational approaches related to using the capabilities of the allies in the area of the operation or outsourcing through NSPA.

\section{Analysis of the use of outsourcing services for the provision of security to the structures of the Bulgarian Armed Forces}

The possibilities for providing security of military units and the facilities in the units of the Bulgarian Armed Forces are either through hiring an external security company, or by using their own resources.

Experience so far shows that the use of outsourcing in this direction is ineffective. This raises a number of reasons. In the foreground stands the low quality of the provided service. Another negative is the aging staff which the company uses to provide the service. The reasons for these negatives are mainly the low pay of the guards provided by the contractor as compared to the resources that the Ministry of Defence allocates to each guard. According to the National Association of Industrial Security Companies, the overall cost to the employer for the wage of a security guard in 2012 was 447.86 levs. The average net amount that the guards receive annually is 298.03 levs. On the other hand, according to experts from the Ministry of Defence, the amount that the companies receive for a guard is approximately 700 levs [3]. In these circumstances, it is quite easy to explain the reluctance of young people to apply for the this job. This is the basic reason for the lower quality of the provided service. And the nature of security business, which is mainly connected with passing very long distances, lack of enough sleep, responsibility and possible use of weapons, is in itself indicative that the effective implementation by security guards employed in retirement is hard to achieve.

Another important problem of using external security company in the field of armed forces is caused by the fact that the guards are not directly subordinate to the military units in which they perform the service. This leads to frustration in certain situations and to the inability to require them to perform their specific duties.

There have also been cases of theft by guards, which should not be underestimated. In confirmation of this is the number of prosecutions against security companies for missing property in the facilities guarded by them. The Bulgarian Armed Forces impose fines on contractors who guard closed military sites. In this relation, relevant reports have been announced in public space which show that the Ministry of Defence has claims on private security companies for damages, amounting to 538,521 levs for the period January 1, 2009 - October 31, 2011. The imposed fines for missing property have a priority among them (according to data for 2010). The object of unlawful activities is mainly property such as doors, sinks, radiators, rails, plates, etc. For this period, the companies have received statements for the lacks amounting to 376,176 levs, and the 
majority of them, however, are appealed by the companies and there is no information on the possibility of recoup the damage and the harm done to the Ministry of Defence [9].

All this leads us to the conclusion about the appropriateness of the discussion which is more profitable for the Bulgarian Armed Forces in terms of the studied activity outsourcing services in the field of security or the appointment of full-time employees for this activity. The decisions in this direction should be based on relevant analytical estimates of the cost that the Ministry of Defence pays for a security guard in both alternatives.

Based on the minimum wage -290 levs for 2012 in which the majority of military units still used outside contractors for security, the average gross monthly salary of a civilian security guard assigned to work in the Bulgarian Armed Forces amounted to 589.25 levs. This figure includes not only the minimum wage, but also the average sum of the grade of service at the rate of $1 \%$ for each year of service, a supplement for working for the Ministry of Defence - 32\% ration -30 levs per month, additional pay for food when on duty, payment for working at night and on official holidays. To this should be added the amounts for clothing, received once a year, determined by a ministerial order. After adding the social security payments made by the employer which amount to $18.1 \%$ (52.49 levs), the cost is obtained that the Bulgarian Armed Forces pay as a salary in the amount of 641.74 levs. When accounting for the fact that an employee paid 12.9\% (76.01 levs) of that amount for social security and $10 \%$ tax (51.32 levs), the pure amount received by a guard assigned to work for the military amounted to 461.91 levs. These calculations show that a civilian security guard recruited by the Bulgarian Armed Forces in 2012 cost the Ministry of Defence 6833 levs a year, excluding the costs for food and night work during his annual leave [3].

For a year, considering the amount referred to above (700 levs) that the Ministry of
Defence paid the contractors by 2012 for a guard, the annual cost is 8,400 levs. Thus, it appears that there is a difference from 1,567 levs a year for each guard (Figure 2).

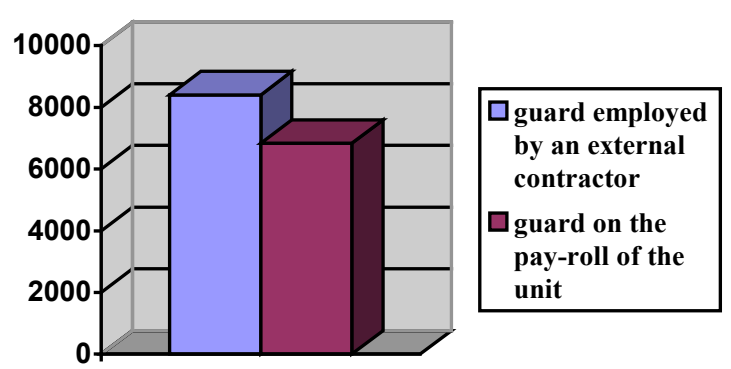

\section{Figure 2: Graphic display of the cost of one} guard in 2012

Multiplied by the number of guards, for whom the Ministry of Defence transferred funds, that amount is increased many times. The above analytical estimates attest that:

- the guards appointed by the contractors to perform the security service, receive very low pay, which is why they can not find suitable employees to ensure the necessary quality of service;

- using outsourcing to provide the security of military areas, commanders /heads/ have no direct control over the work of the guards as they are not in the pay-roll of the respective unit;

- for the Ministry of Defence of the Republic of Bulgaria, outsourcing the security of its subordinate structures has been an unacceptable option so far because it does not lead to the fulfillment of the main objectives of the outsourcing - saving financial resources and improving the quality of services performed.

\section{Conclusion}

The use of outsourcing in the armed forces makes it possible to increase the efficiency of invested funds to improve the national defence of a country. It is necessary to concentrate efforts on its implementation on a broader scale, in terms of activities and services related to the support of he armed 
forces. Its duration, scope and implementation provides an opportunity to focus the attention of the military to fulfill

their basic tasks dictated by the specifics of the military profession.

\section{References}

[1] Memorandum written by the deputy commander of Logistics of the National Guards Unit to the commander of the National Guards Unit in 2015 on starting a procedure for selecting a contractor for the preparation and delivery of food to the National Guards Unit.

[2] Memorandum written by the head of the Logistics section of N. Y. Vaptsarov Naval Academy to the commandant of the N. Y. Vaptsarov Naval Academy with a Reg. № 162/20.01.2014 on catering for the cadets at the N. Y. Vaptsarov Naval Academy.

[3] Peycheva, K. Effectiveness of Outsourcing in the Bulgarian Armed Forces - problematic areas", Almanac 2/2013, National Security and Defence Faculty, G. S. Rakovski Defence College

[4] Peycheva, K. "The Public Sector of Defence and its Interaction with the Private Sector", report on the scientific conference "Market Development of the Bulgarian Economy Two Decades after the Change", 2010, D. A. Tsenov Academy of Economics Svishtov, p. 212.

[5] Letter with a Reg. № 101-228/14.02.2006 from the Chief of the General Staff of the Bulgarian Armed Forces.

[6] Letter with a Reg. № 1240/25.03.2014 sent to the Rector of the Vasil Levski national Military University to the head of the Logictics Directorate.

[7] Comparative Analisys of the catering at the Vasil Levski NMU and Measures for its Improvement in 2014.

[8] The Army Will Eat Sandwiches, They Stopped the Catering, http://www.24chasa.bg/ Article.asp?ArticleId=524259 03.11.2015

[9] Morkin, D. "The Armed Forces Fined Security Companies" - Newspaper Trud, 12.02.2012, http://www.trud.bg/Article.asp?ArticleId=1228352.

[10] Sevdalina Dimitrova, Nikolay Nichev, Nikolay Stefanov. Development of Outsourcing Services. (2015). International Conference Knowledge-Based Organisation. Volume 21, Issue 1, pp. 192-197

[11] Nichev, N. Theoretical Foundations of Military Logistics - Organisation of Logistical Support. Vasil Levski National Military University, V. Tarnovo, Bulgaria, 2011, p. 140

[12] Terziev, V., Nichev, N., Bankov, S., Corruption and National Security. (2016) International Scientific Journal "Innovation research", №10, part 3, pp. 189-196

[13] Terziev, V., Filipov, S., Ninth International Scientific Conference 17-19.6.2016, Durres, Republic of Albania. "Characteristics and Elements of Military Infrastructure", Volume 13.1., p. 300

[14] Banabakova, V. Logistics and Development of Economy. Buletin Stiintific. Land Forces Academy, Sibiu, Romania, N. 1, 2013, p. 6.

[15] Banabakova, V., Sv. Stefanov. State and Development of Logistics Services in Bulgaria. Land Forces Academy Review, Sibiu, Romania, N. 2, 2013, p. 157.

[16] Nichev, N., Petrova, E., Professional Training of Future Logistic Officers at the National Military University of Bulgaria, Sibiu, Romania, The 21st KBO, 2015, pp. $259 \div 263$. 